\title{
DETERMINATION OF ARYLTETRALIN-LIGNANS AND BIOACTIVITY SCREENING OF LINUM ARBOREUM L. FROM TURKEY
}

\author{
ZAHER SULTAN ${ }^{1}$, HAJAR HEYDARI ${ }^{1}$, ASLI KOC ${ }^{2}$, ABDURRAHMAN AYGUL $^{3}$, BELMA \\ KONUKLUGIL ${ }^{4 *}$ \\ ${ }^{1}$ Pharmacognosy Department, Pharmacy Faculty, Ankara University, Tandoğan, 06100 Ankara, Turkey \\ ${ }^{2}$ Biochemistry Department, Pharmacy Faculty, Ankara University, Tandoğan, 06100 Ankara, Turkey \\ ${ }^{3}$ Pharmaceutical Microbiology Department, Pharmacy Faculty, Cukurova University, Sarlçam, 01330 Adana, Turkey \\ ${ }^{4}$ Pharmacognosy Department, Faculty of Pharmacy, Lokman Hekim University, Söğ̈̈tözü, 06510 Çankaya, Ankara, Turkey
}

*corresponding author: belma.konuklugil@gmail.com

Manuscript received: December 2020

\begin{abstract}
The objectives of this study were to analyse the presence of two aryltetralin group lignans (podophyllotoxin and picropodophyllotoxin), in order to evaluate the total phenolic and the flavone contents and to determine the biological activities of Linum arboreum. Aryltetralin-lignans are major compounds of Linum genus. In this study, a fast, simple, accurate and selective HPLC method was performed for the qualitative and quantitative analysis of podophyllotoxin and picropodophyllotoxin, by using reverse-phase high performance liquid chromatography (HPLC) with diode array detector (DAD). The HPLC analysis was performed on different fractions, obtained by using methanol, ethyl acetate, water, hexane and chloroform as extraction solvents, from both seeds and aerial parts. The identification of podophyllotoxin and picropodophyllotoxin is based on the retention time and the UV spectra by comparison with standards. According to the International Conference on Harmonization (ICH) guidelines, the method was evaluated, and precision, accuracy, and reproducibility of the method have been apparent from good linearity. Podophyllotoxin and picropodophyllotoxin were found in the aerial parts of L. arboreum L. in higher amounts than seeds Furthermore, total phenolic and total flavonoid contents and antioxidant, cytotoxicity and antimicrobial activity of $L$. arboreum were investigated. While the fractions presented dose dependent antioxidant activity, they exhibited weak antimicrobial activity. The seeds ethyl acetate fraction presented the highest cytotoxic activity against HCT-116 cell line. The fractions have shown dose dependent antioxidant activity.
\end{abstract}

\section{Rezumat}

Obiectivul acestui studiu a fost investigarea a doi lignani din grupul ariltetralinei (podofilotoxina și picropodofilotoxina) în vederea evaluării conținutului total de fenoli și flavone ce definesc activitatea biologică a speciei Linum arboreum. S-a utilizat o metodă HPLC în fază inversă, iar extractele vegetale au fost obținute din semințe și părți aeriene. Identificarea podofilotoxinei și a picropodofilotoxinei a fost realizată prin compararea timpilor de retenție și a spectrelor UV ale probelor și standardelor. Metoda a fost validată conform ghidurilor ICH. Podofilotoxina și picropodofilotoxina s-au regăsit în concentrație mai mare în extractele obținute din părți aeriene decât în cele din semințe. Fracțiile obținute au prezentat acțiune antioxidantă pronunțată și activitate antimicrobiană slabă. Fracția obținută în acetat de etil din semințe a prezentat activitate citotoxică asupra liniei celulare HCT-116.

Keywords: aryltetralin-lignan, bioactivity, podophyllotoxin, picropodophyllotoxin

\section{Introduction}

The genus Linum belongs to the Linaceae family, having more than 200 species. Linum species are known with their lignin type secondary metabolites such as aryltetralin lignan, flavonolignans and arylnaphthalene lignans $[1,2]$. Lignans are found in higher plants, produced naturally via peroxidases and laccases enzymes and are generated by oxidative dimerization of two phenylpropanoid units [3, 4]. These secondary metabolites from higher plants have shown antiviral, anticancer [5], anti-inflammatory, antimicrobial, antioxidant [6] and hepatoprotective [7] activities. Aryltetralin-lignan such as 6-methoxy podophyllo- toxin, its glycosides and ester derivatives are the most common lignans in Linum species. Podophyllotoxin derivatives are used as strong chemotherapeutic agents in cell lung carcinoma, testicular cancer, and malignant lymphoma treatment [8]. Many structures identification, biological activities, and mechanism action of podophyllotoxins have been carried out showing that these secondary metabolites have prominent position among natural secondary metabolites. Aryltetralin lignans are the starting materials for the semisynthetic of etoposide and teniposide drugs that emphasize the importance of this group of secondary metabolites [9]. To our knowledge, the phytochemical and bioactivity studies regarding $L$. arboreum are 
scarce. For this reason, two different parts of the plant were selected as study material and some bioactivities that were not investigated before were analysed.

In this study, a quality control method was set up to determine the podophyllotoxin and picropodophyllotoxin contents in Linum arboreum, which is collected from Turkey (Muğla). Furthermore, total phenolic component, total flavonoid content, antioxidant, antibacterial and cytotoxicity of $L$. arboreum were determined.

\section{Materials and Methods}

\section{General}

Quercetin, 3-(4,5-dimethyl-2-thiazolyl)-2,5-diphenyl2H-terazoliumbromide (MTT), 1,1-Diphenyl-2-picrylhydrazyl (DPPH), sulfanilamide, napthylethylenediamine dihydrochloride, podophyllotoxin and picropodophyllotoxin were purchased from Sigma Aldrich, and all solvents were purchased from Merck. McCoy's 5A medium, foetal bovine serum (FBS), streptomycin and glutamine were from PAA (PAsching, Austria), and Bert Vogelstein kindly provided HCT 116 colon cancer cells. The compositional analysis was performed by reverse-phase high-performance liquid chromatography (Agilent Technologies, USA) with a diode array detector. A microplate reader (Molecular Devices, USA) was used in the antioxidant activity assays.

\section{Plant material and the extract preparation}

L. arboreum was collected from Muğla Turkey in August 2015. Voucher species (No: 17073) were identified and plant samples deposited for future reference in Ankara University, Faculty of Pharmacy, Kamil Karamanoglu Herbarium (AEF). The dried and powdered aerial part (275.59 g) and seeds (164.17 g) of L. arboreum were extracted with methanol for 12 hours. The residue was evaporated under the vacuum and dried. The aerial part extract (24.71 g) and the seed extract $(14.35 \mathrm{~g})$ were partitioned successively between $\mathrm{H}_{2} \mathrm{O}$ and n-hexane, $\mathrm{CHCl}_{3}$, EtOAc, the residue or water fraction. All fractions were kept at $4^{\circ} \mathrm{C}$ until used.

Determination of podophyllotoxin and picropodophyllotoxin

A stock solution of podophyllotoxin and picropodophyllotoxin $(100 \mu \mathrm{g} / \mathrm{mL})$ was prepared and filtered through $0.45 \mu \mathrm{m}$ membranes. The calibration curve was prepared by using the 100, 50, 25, 10 and 5 ppm stock solution of standards. HPLC analysis was performed by a reverse-phase column $(150 \times 4.6$ $\mathrm{mm}$ i.d, $5 \mu \mathrm{m})$, on a gradient program, A: $0.02 \%$ phosphoric acid in water; B: Methanol and flow rate of $1 \mathrm{~mL} / \mathrm{min}$. The mobile phase consisting of solution $\mathrm{A}$ and solution $\mathrm{B}$ is as follows: gradient system from 0 - $17 \mathrm{~min}, 40 \% \mathrm{~A} ; 17 \mathrm{~min}, 67 \% \mathrm{~A} ; 18$ $\min 40 \%$ A, $8-12 \min , 90 \mathrm{~A}$. The injection volume was $20 \mu \mathrm{L}$. The signals were detected at $210 \mathrm{~nm}$ by DAD detection with the column temperature at $25^{\circ} \mathrm{C}$. The identification of podophyllotoxin and picropodophyllotoxin was performed by comparing retention times and spectral data with the ones obtained with standards. Calibration curves were used for quantification. [10].

Validation of the HPLC method

According to ICH guidelines, the method validation was evaluated in terms of linearity, detection limits, quantification limits, recovery, precision and selectivity [10].

Determination linearity

Podophyllotoxin and picropodophyllotoxin (100, $50,25,10$ and $5 \mathrm{ppm})$ were analysed by a reversephase column $(150 \times 4.6 \mathrm{~mm}$ i.d, $5 \mu \mathrm{m})$, on a gradient program in three replicates. Calibration curves were obtained by plotting the peak areas against each concentration of standard solutions and the linear regression equation and value of correlation coefficient were established.

\section{Determination of $L O D$ and $L O Q$}

The LOD (limit of detection) and LOQ (limit of quantification) were estimated by a signal-to-noise ratio $(\mathrm{S} / \mathrm{N})$, for LOD threefold of $\mathrm{S} / \mathrm{N}$ and for $\mathrm{LOQ}$ tenfold of $\mathrm{S} / \mathrm{N}$ are accepted.

Recovery studies

For the recovery (accuracy assay) of the method, the fractions of $L$. arboreum were spiked with known amounts of podophyllotoxin and picropodophyllotoxin standard solutions at 5,25 and $50 \mu \mathrm{g} / \mathrm{mL}$ concentrations. The mean of recovered concentration was accepted as accuracy value and presented as recovery percentage.

\section{Determination of precision}

The intra-day and inter-day precision were determined. For intra-day precision, all analysis were determined in triplicate in a day, and for inter-day precision, all analysis were determined in triplicate during three different days. The relative standard deviation of retention times and peak areas were accepted as precision:

$$
\mathrm{RSD} \%=(\mathrm{SD} / \mathrm{Mean}) \times 100 .
$$

\section{Determination of selectivity}

The method selectivity was appraised by the resolution study between the standard peaks.

Total soluble phenolic content assay

The total phenolic contents of fractions of $L$. arboreum L. were calculated by using the FolinCiocâlteu reagent as described by Singleton and Rossi [11]. Total phenolic contents were standardized against gallic acid and expressed as microgram per litre of gallic acid equivalents (GAE). The linearity range for this assay was determined as $0.5-5.0 \mu \mathrm{g} / \mathrm{L}$ GAE $\left(\mathrm{R}^{2}=0.9993\right)$, giving an absorbance range of $0.050-0.555 \mathrm{AU}$. For the determination of total phenolic contents of L. arboreum L. fractions, $5 \mathrm{~mL}$ 
of Nanopure water, 0.5 - $1.0 \mathrm{~mL}$ of sample, and 1.0 $\mathrm{mL}$ of Folin-Ciocâlteu reagent were added to a 25 $\mathrm{mL}$ volumetric flask and allowed to stand at $25^{\circ} \mathrm{C}$. After $8 \mathrm{~min}, 10 \mathrm{~mL}$ of a $7 \%$ sodium carbonate solution was added, followed by Nanopure water filled to volume. The mixture was kept at $25^{\circ} \mathrm{C}$ for 2 hours. The absorbance of the samples was measured by a using a spectrophotometer at $750 \mathrm{~nm}$.

Total flavonoid content assay

The fractions $(2 \mathrm{mg} / \mathrm{mL})$ and distilled water were mixed in 1:3 ratio. Next, $0.075 \mathrm{~mL}$ of $5 \% \mathrm{NaNO}_{2}$ $(\mathrm{w} / \mathrm{v})$ were added and vortexed. After $5 \mathrm{~min}, 0.15$ $\mathrm{mL}$ of $10 \% \mathrm{AlCl}_{3}(\mathrm{w} / \mathrm{v})$ were added to the tubes and allowed to stand at $25^{\circ} \mathrm{C}$ for $6 \mathrm{~min}$. The final volume was made to $3 \mathrm{~mL}$ with distilled water and $0.5 \mathrm{~mL}$ of $\mathrm{NaOH}(1 \mathrm{M})$. The absorbance was measured against a blank at $510 \mathrm{~nm}$. Quercetin was used as a standard for a calibration curve. The flavonoid content was calculated by using the quercetin calibration equation $[12,13]$.

\section{DPPH antioxidant activity determination}

Different concentrations of fractions were added to an equal volume to methanolic DPPH solution ( 0.1 $\mathrm{mM}$ ) and allowed to stand at room temperature for $30 \mathrm{~min}$, and the absorbance was recorded at $517 \mathrm{~nm}$. Quercetin was used as standard [14].

Superoxide radical scavenging activity by alkaline DMSO method (SO)

Superoxide radical was generated in the nonenzymatic system. To $1 \mathrm{~mL}$ of alkaline DMSO $(5 \mathrm{mM} \mathrm{NaOH}$ in $0.1 \mathrm{~mL}$ water) we added $10 \mu \mathrm{L}$ of NBT $(1 \mathrm{mg} / \mathrm{mL})$ and $30 \mu \mathrm{L}$ of different concentrations of fractions or standard compounds. DMSO was added to vials to obtain a final volume of $140 \mu \mathrm{L}$. The absorbance was measured at $560 \mathrm{~nm}$ using a microplate reader [15]. Nitric oxide radical scavenging activity $(\mathrm{NO})$ Briefly, $60 \mu \mathrm{L}$ of sodium nitroprusside $(10 \mathrm{mM} / \mathrm{in}$ phosphate-buffered saline) were dissolved and added to $60 \mu \mathrm{L}$ of serially diluted extracts and incubated at $25^{\circ} \mathrm{C}$ for $150 \mathrm{~min}$. Finally, an equal volume of Griess reagent (1\% sulfanilamide, $0.1 \%$ naphthyl ethylenediamine dihydrochloride, $2.5 \% \mathrm{H}_{3} \mathrm{PO}_{4}$ ) was added into each well in order to measure the nitrite content. The chromophore was formed at $25^{\circ} \mathrm{C}$ in $10 \mathrm{~min}$. The vials' absorbance was measured at 577 $\mathrm{nm}$ in a microplate reader [16].

Radical scavenging activity was calculated by using the following formula:

\section{Inhibition $\%=[($ Absorbance control - Absorbance sample)/Absorbance control] $\times 100$.}

The $\mathrm{IC}_{50}$ for antioxidant activities was obtained through extrapolation from the regression analysis. The antioxidant activity was evaluated based on this $\mathrm{IC}_{50}$ value.

Cell Culture

HCT-116 colon cancer cells were grown in RPMI1640 medium supplemented with $10 \%$ foetal bovine serum, $2 \mathrm{mM}$ L-glutamine, $100 \mathrm{U} / \mathrm{mL}$ penicillin, $100 \mu \mathrm{g} / \mathrm{mL}$ streptomycin, incubated at $37^{\circ} \mathrm{C}$, in $5 \%$ $\mathrm{CO}_{2}$. When cells were $80 \%$ confluent, they were passaged by trypsinization.

Cell viability assay

To test the cytotoxic activity of $L$. arboreum $\mathrm{L}$. fractions against HCT-116 colon cancer cells, the MTT (3-(4,5-Dimethylthiazol-2-yl)-2,5-Diphenyltetrazolium Bromide) test was performed [17]. For this purpose, HCT-116 cells $\left(2 \times 10^{4}\right)$ were seeded to the 96 well plates. After overnight incubation, cells were incubated with different concentrations of $L$. arboreum L. fractions $(1-60 \mu \mathrm{g} / \mathrm{mL})$ for 72 hours. Stock solutions of L. arboreum L. fractions were prepared in DMSO. The final DMSO concentration wasn't allowed to exceed $0.5 \%$, and equal amounts of DMSO were added to the control group. Camptothecin was used as a positive control. MTT solution (5 mg/ $\mathrm{mL}$ ) was prepared in PBS, and cells were incubated with MTT solution for 4 hours. Insoluble formazan crystals were dissolved by adding acidified SDS solution. Absorbance measurement at $550 \mathrm{~nm}$ was performed with a microplate reader (Thermo, USA). $\mathrm{IC}_{50}$ values were calculated using GraphPad Prism 7.0 software (GraphPad Software, USA).

Antimicrobial activity

All fractions and crude extracts were tested for their antimicrobial activity against Escherichia coli (ATCC 25922), Enterococcus faecalis (ATCC 29212), Staphylococcus aureus (ATCC 29213), Pseudomonas aeruginosa (ATCC 27853) as bacterial strains, and Candida albicans (ATCC 14053), Candida krusei (ATCC 6258) as yeast strains. All extracts were solved in DMSO and sterilized by filtering through $0.2 \mu \mathrm{m}$ membrane filter. MIC was determined by the microdilution method in 96-well U-based microplates according to EUCAST standards. Accordingly, Mueller-Hinton Broth (MHB) was used for bacteria and Roswell Park Memorial Institute (RPMI) 1640 medium for yeasts. In the microplates, serial dilutions of extracts in $50 \mu \mathrm{L}$ volumes were conducted with a suitable medium. Inoculums were prepared by diluting bacteria suspensions in MHB at 100 times and fungal suspensions in RPMI 1640 at 10-fold with 0.5 McFarland density. Prepared inoculums were added in equal volume $(50 \mu \mathrm{L})$ to the microplate wells in which the serial dilutions were made. After 24 hours of incubation at $37^{\circ} \mathrm{C}$, the microplates were evaluated visually, and the lowest concentration without visible growth for each extract was considered as minimum inhibitory concentration $[18,19]$.

\section{Results and Discussion}

The methanolic extracts of aerial part and seeds of L. arboreum were partitioned by liquid-liquid extraction. The obtained fractions and their weights are listed in Table I. In this study we investigated 
and quantified the amount of podophyllotoxin and picropodophyllotoxin by HPLC-DAD in L. arboreum. The calibration curve of standards for both molecules was established, and the equation was determined as $\mathrm{y}=1649.3 \mathrm{x}+1638$ for podophyllotoxin and $\mathrm{y}=$ $5101.5 x+81.255$ for picropodophyllotoxin. The correlation coefficient was calculated as $\mathrm{R}^{2}=0.9998$ and 0.9998 , respectively. As a result of the HPLC analysis, while podophyllotoxin was determined in aerial part (the hexane fraction) and seeds (the chloroformed fraction), the picropodophyllotoxin was determined in ethyl acetate fractions of aerial part and seeds.

Table I

Fractions of aerial part and seeds of L. arboreum L.

\begin{tabular}{|c|c|c|c|}
\hline & Fractions & Weight (g) & Yields \% \\
\hline \multirow{4}{*}{ Aerial part } & Methanol (AM) & 24.71 & 8.96 \\
\cline { 2 - 4 } & n-Hexane (AH) & 4.53 & 1.57 \\
\cline { 2 - 4 } & Chloroform (AC) & 2.65 & 0.96 \\
\cline { 2 - 4 } & Ethyl acetate (AE) & 5.30 & 1.92 \\
\cline { 2 - 4 } & Water (AW) & 11.08 & 4.02 \\
\hline \multirow{5}{*}{ Seeds } & Methanol (SM) & 14.35 & 8.74 \\
\cline { 2 - 4 } & n-Hexane (SH) & 4.15 & 2.52 \\
\cline { 2 - 4 } & Chloroform (SC) & 3.68 & 2.24 \\
\cline { 2 - 4 } & Ethyl acetate (SE) & 1.88 & 1.14 \\
\cline { 2 - 4 } & Water (SW) & 3.57 & 2.17 \\
\hline
\end{tabular}

The precision, accuracy, and reproducibility of the method were apparent from good linearity. LOD and LOQ values, \%RSD values for intra-day (repeatability) and inter-day (intermediate precision), the recovery values are indicated in Table II. Furthermore, the results demonstrated that the quantitative method was precise, accurate, and sensitive.

The antioxidant activity of the aqueous, and the ethylacetate fractions were evaluated using 3 different assays: (1) DPPH (2) SO and (3) NO. All fractions were subject to the antioxidant activity assays. The results are presented in Table III. According to the results, while the methanolic and aqueous fractions obtained from the aerial parts showed higher antioxidant activity than other fractions. In the DDPH assay, the nitric oxide and superoxide scavenging activities performed on the aqueous and ethylacetate fractions obtained from the seed showed higher antioxidant activity than other fractions.

Table II

Quantification data for podophyllotoxin and picropodophyllotoxin in L. arboreum L. fractions

\begin{tabular}{|c|c|}
\hline \multicolumn{2}{|l|}{ Podophyllotoxin } \\
\hline LOD & $0.17 \mu \mathrm{g} / \mathrm{mL}$ \\
\hline LOQ & $0.51 \mu \mathrm{g} / \mathrm{mL}$ \\
\hline AH fraction & $45.4 \mu \mathrm{g} / \mathrm{g}_{\text {dried plant }}$ \\
\hline RSD\% Intra-day (Repeatability) & $0.03 \%$ \\
\hline $\begin{array}{l}\text { RSD\% Inter-day (Intermediate } \\
\text { Precision) }\end{array}$ & $0.23 \%$ \\
\hline Recovery & $98.1 \%-103.5 \%$. \\
\hline SC fraction & $36.4 \mu \mathrm{g} / \mathrm{g}_{\text {dried plant }}$ \\
\hline RSD\% Intra-day (Repeatability) & $0.05 \%$ \\
\hline $\begin{array}{l}\text { RSD\% Inter-day (Intermediate } \\
\text { Precision) }\end{array}$ & $0.15 \%$ \\
\hline Recovery & $99.2 \%-101.8 \%$. \\
\hline \multicolumn{2}{|c|}{ Picropodophyllotoxin } \\
\hline LOD & $0.15 \mu \mathrm{g} / \mathrm{mL}$ \\
\hline LOQ & $0.45 \mu \mathrm{g} / \mathrm{mL}$ \\
\hline AE fraction & $12.1 \mu \mathrm{g} / \mathrm{g}_{\text {dried plant }}$ \\
\hline RSD\% Intra-day (Repeatability) & $0.07 \%$ \\
\hline $\begin{array}{l}\text { RSD\% Inter-day (Intermediate } \\
\text { Precision) }\end{array}$ & $0.29 \%$ \\
\hline Recovery & $95.6 \%-102.7 \%$. \\
\hline SE fraction & $10.3 \mu \mathrm{g} / \mathrm{g}_{\text {dried plant }}$ \\
\hline RSD\% Intra-day (Repeatability) & $0.08 \%$ \\
\hline $\begin{array}{l}\text { RSD\% Inter-day (Intermediate } \\
\text { Precision) }\end{array}$ & $0.24 \%$ \\
\hline Recovery & $99.3 \%-101.1 \%$. \\
\hline
\end{tabular}

Total phenolic and total flavonoid contents of $L$. arboreum fractions are presented in Table IV. For the total phenolic contents, the calibration curve of gallic acid was established. The equation was determined as: $y=0.451 x+0.0238$, and the correlation coefficient was calculated as $\mathrm{R}^{2}=0.9993$. For the total flavonoid contents, the calibration curve of quercetin was established. The equation was determined as: $\mathrm{y}=$ $0.1491 \mathrm{x}+0.0063$, and the correlation coefficient was calculated as $\mathrm{R}^{2}=0.9994$.

Table III

Antioxidant activity of $L$. arboreum L. fractions

\begin{tabular}{|c|c|c|c|c|}
\hline \multicolumn{5}{|c|}{$\mathbf{I C}_{\mathbf{5 0}} \boldsymbol{\mu g} / \mathbf{m L} \pm \mathbf{S D}$} \\
\hline & Fractions & $\mathbf{D P P H}$ & $\mathbf{S O}$ & NO \\
\hline \multirow{4}{*}{ Aerial part } & $\mathrm{AM}$ & $85.1 \pm 0.1$ & $96.8 \pm 0.15$ & $117.1 \pm 0.23$ \\
\cline { 2 - 5 } & $\mathrm{AH}$ & $112.3 \pm 0.12$ & $128.6 \pm 0.22$ & $132.5 \pm 0.33$ \\
\cline { 2 - 5 } & $\mathrm{AC}$ & $135.9 \pm 0.21$ & $142.3 \pm 0.27$ & $151.6 \pm 0.11$ \\
\cline { 2 - 5 } & $\mathrm{AE}$ & $87.6 \pm 0.14$ & $101.7 \pm 0.19$ & $120.4 \pm 0.12$ \\
\cline { 2 - 5 } & $\mathrm{AW}$ & $78.4 \pm 0.26$ & $85.5 \pm 0.12$ & $98.1 \pm 0.19$ \\
\hline \multirow{5}{*}{ Seeds } & $\mathrm{SM}$ & $93.8 \pm 0.32$ & $111.8 \pm 0.33$ & $125.3 \pm 0.31$ \\
\cline { 2 - 5 } & $\mathrm{SH}$ & $125.2 \pm 0.19$ & $139.3 \pm 0.31$ & $147.8 \pm 0.15$ \\
\cline { 2 - 5 } & $\mathrm{SC}$ & $144.8 \pm 0.2$ & $153.2 \pm 0.29$ & $168.6 \pm 0.24$ \\
\cline { 2 - 5 } & $\mathrm{SE}$ & $98.5 \pm 0.34$ & $109.5 \pm 0.24$ & $116.1 \pm 0.19$ \\
\cline { 2 - 5 } & $\mathrm{SW}$ & $81.3 \pm 0.28$ & $99.8 \pm 0.31$ & $109.5 \pm 0.16$ \\
\cline { 2 - 5 } & Quercetin & $8.23 \pm 0.1$ & $11.2 \pm 0.21$ & $13.1 \pm 0.11$ \\
\hline
\end{tabular}


FARMACIA, 2021, Vol. 69, 5

\section{Table IV}

Total phenolic and total flavonoid contents of $L$. arboreum $\mathrm{L}$. fractions

\begin{tabular}{|c|c|c|c|}
\hline \multicolumn{4}{|c|}{$\boldsymbol{\mu g} / \mathbf{m g}_{\text {extract }} \mathbf{\pm}$ SD } \\
\hline & Fractions & Total phenolic & Total flavonoid \\
\hline \multirow{4}{*}{ Aerial part } & $\mathrm{AM}$ & $40.7 \pm 0.08$ & $55.4 \pm 0.01$ \\
\cline { 2 - 4 } & $\mathrm{AH}$ & $25.2 \pm 0.09$ & $30.1 \pm 0.07$ \\
\cline { 2 - 4 } & $\mathrm{AC}$ & $37.0 \pm 0.08$ & $20.5 \pm 0.01$ \\
\cline { 2 - 4 } & $\mathrm{AE}$ & $42.1 \pm 0.05$ & $41.3 \pm 0.08$ \\
\cline { 2 - 4 } & $\mathrm{AW}$ & $26.0 \pm 0.02$ & $45.9 \pm 0.01$ \\
\hline \multirow{4}{*}{ Seeds } & $\mathrm{SM}$ & $24.9 \pm 0.04$ & $39.5 \pm 0.07$ \\
\cline { 2 - 4 } & $\mathrm{SH}$ & $12.5 \pm 0.06$ & $20.7 \pm 0.01$ \\
\cline { 2 - 4 } & $\mathrm{SC}$ & $32.5 \pm 0.04$ & $29.3 \pm 0.01$ \\
\cline { 2 - 4 } & $\mathrm{SE}$ & $36.8 \pm 0.02$ & $31.2 \pm 0.07$ \\
\cline { 2 - 4 } & $\mathrm{SW}$ & $21.3 \pm 0.08$ & $40.8 \pm 0.08$ \\
\hline
\end{tabular}

While a major of phenolic substances was found in the ethyl acetate fractions of $L$. arboreum aerial parts and seeds, abundant flavonoid groups were detected in the aqueous fractions. The results of the present antioxidant study showed that phenolic compounds and flavonoids are the main contributors to the antioxidant activity of L. arboretum.
L. arboreum fractions have shown dose-dependent cytotoxic activity against HCT-116; results were shown in Table V. The ethyl acetate fraction of seeds presented the highest cytotoxic activity $\left(\mathrm{IC}_{50} 7.09 \mu \mathrm{g} / \mathrm{mL}\right)$. The $\mathrm{n}$-hexane and aqueous fractions of seeds and aerial part exhibited moderate cytotoxic activity against HCT-116 cell lines.

Table V

Cytotoxic activities of $L$. arboreum L. fractions

\begin{tabular}{|c|c|c|}
\hline \multicolumn{3}{|c|}{$\mathbf{I C}_{\mathbf{5 0}} \boldsymbol{\mu g} / \mathbf{m L} \pm \mathbf{S D}$} \\
\hline & Fractions & HCT-116 \\
\hline \multirow{4}{*}{ Aerial part } & $\mathrm{AM}$ & $>40$ \\
\cline { 2 - 3 } & $\mathrm{AH}$ & $29.23 \pm 4.41$ \\
\cline { 2 - 3 } & $\mathrm{AC}$ & $>40$ \\
\cline { 2 - 3 } & $\mathrm{AE}$ & $>40$ \\
\cline { 2 - 3 } Seeds & $\mathrm{AW}$ & $20.34 \pm 2.09$ \\
\hline \multirow{5}{*}{} & $\mathrm{SM}$ & $>40$ \\
\cline { 2 - 3 } & $\mathrm{SH}$ & $22.2 \pm 3.4$ \\
\cline { 2 - 3 } & $\mathrm{SC}$ & $>40$ \\
\cline { 2 - 3 } & $\mathrm{SE}$ & $7.09 \pm 0.73$ \\
\cline { 2 - 3 } & $\mathrm{SW}$ & $12.84 \pm 1.62$ \\
\cline { 2 - 3 } & Camptothecin & $0.151 \pm 0.014$ \\
\hline
\end{tabular}

Table VI

Antimicrobial activity of L. arboreum L. fractions

\begin{tabular}{|c|c|c|c|c|c|c|c|}
\hline \multicolumn{8}{|c|}{$\mathrm{MIC}(\mathrm{mg} / \mathrm{mL})$} \\
\hline \multicolumn{2}{|c|}{ Fractions } & 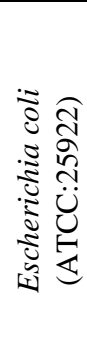 & 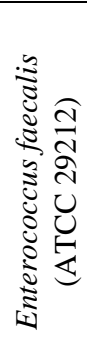 & 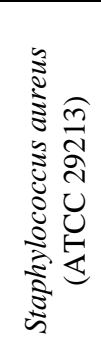 & 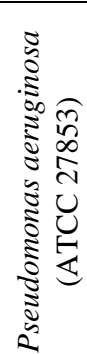 & 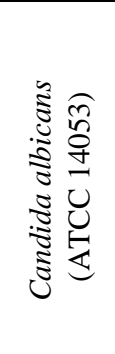 & 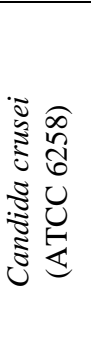 \\
\hline \multirow{5}{*}{ Aerial part } & $\mathrm{AM}$ & - & 0.938 & 1.875 & - & - & - \\
\hline & $\mathrm{AH}$ & - & - & - & - & - & - \\
\hline & $\mathrm{AC}$ & - & 0.992 & - & - & - & - \\
\hline & $\mathrm{AE}$ & - & - & 2.891 & - & - & - \\
\hline & $\mathrm{AW}$ & - & 0.859 & 1.719 & - & - & - \\
\hline \multirow{5}{*}{ Seeds } & SM & - & - & - & - & - & - \\
\hline & $\mathrm{SH}$ & - & - & - & - & - & - \\
\hline & $\mathrm{SC}$ & - & - & - & - & - & - \\
\hline & SE & - & - & 0.600 & - & - & - \\
\hline & SW & - & - & - & - & - & - \\
\hline \multirow{2}{*}{ Standard } & Gentamicin & 0.001 & 0.016 & 0.0005 & 0.002 & - & - \\
\hline & Fluconazole & $*$ & $*$ & $*$ & $*$ & 0.00025 & 0.032 \\
\hline
\end{tabular}

- not active; $*$ no experiment

According to the antimicrobial results presented in Table VI, among the tested fractions from $L$. arboreum seed extract, only the chloroform fraction was moderately active against $S$. aureus. On the other hand, the aqueous fraction of the aerial part and the crude extract was moderately active against $E$. faecalis and $S$. aureus. Similarly, chloroform and ethyl acetate fractions of the aerial part were also moderately active against E. faecalis and S. aureus, respectively.
As a result, our observations indicate that $L$. arboreum has a moderate antibacterial activity, whereas they did not show antifungal activity.

L. arboreum is an annual plant and does not show over-spread. According to the flora of Turkey, these species are registered in a region in Turkey (Muğla) and two islands in Greece (Karpathos Creete islands) [20]. $\beta$-peltatin, 6-methoxypodophylotoxine with $\beta$ glucose and hexose moiety were detected as the most abundant lignans by means of HPLC-ESI/MS-MS- 
FARMACIA, 2021, Vol. 69, 5

UV/DAD in aerial part of L. arboreum [21]. In this study, we determined and quantified the podophyllotoxin and picropodophyllotoxin amounts (aryltetralin lignans) in L. arboreum L. species, hereby podophyllotoxin and picropodophyllotoxin were found in both aerial parts and seeds of L. arboreum L. For determination, the podophyllotoxin and picropodophyllotoxin as aglycone plant materials were extracted by methanol [9]. Moreover, the methanolic extract of $L$. arboreum presented the highest antioxidant activity rather than aqueous extract [22]. In this study, the methanolic extract was used and fractionation was undertaken for further investigation. Among the two parts of $L$. arboreum, aerial parts had the highest amount of podophyllotoxin and picropodophyllotoxin content.

The bioactivity of plant extracts is mostly due to the phenolic compounds they contain, such as flavonoids and anthocyanosides. Flavonoids showed antioxidant, anti-inflammatory, antinociceptive and cytostatic properties by the regulation of the prostaglandin pathways. Recent studies have showed that flavonoids and phenolic compounds are generally isolated from semi-polar or polar fractions [22, 23]. In our study, the bioactivity of phenols and flavonoid fromthe $L$. arboreum $\mathrm{L}$. fractions were investigated. Polar and semi-polar fractions of seeds and aerial parts showed notable radical scavenging activity because of high phenolic compounds. Ethyl acetate and aqueous fractions also presented high antioxidant activity compared to other fractions. The aerial part fractions contained a higher number of phenolic compounds and flavonoids than seeds fractions. These results were reflected in the results of the studies presenting the antioxidant activity. On the other hand, the most active fraction against HCT116 cell line was the ethyl acetate fraction of seeds. The aqueous and n-hexane fractions were also active against HCT-116 cell line. In terms of antimicrobial activity assays, the highest activity was observed with ethyl acetate fraction of seeds $(0.6 \mathrm{mg} / \mathrm{mL}$ for $S$. aureus $)$. Besides, polar and semipolar fractions from the aerial parts also exhibited moderate antibacterial activity.

\section{Conclusions}

The bioactivity of plant extracts may be due to the content of the secondary metabolites of these extracts like phenolic compounds, alkaloids, saponin and etc. Flavonoids show antioxidant, antiinflammatory, antinociceptive and cytostatic properties through their effect on the prostaglandin's pathway. In this study, bioactivity and total phenolic and the flavonoid contents of $L$. arboreum L. fractions obtained from liquid-liquid extraction were also investigated. Polar and semi polar fractions of seeds and aerial parts showed high radical scavenging activity because of high amounts of phenolic compounds. The methanolic and aqueous fractions were found to have high antioxidant activity compared to other fractions.

The present study revealed that the different fractions of $L$. arboreum have different antioxidant capacities and phenolic or favonoid contents. We performed different antioxidant activity measurements to evaluate different antioxidant capabilities of the samples.

Furthermore, only ethyl acetate fraction of seeds showed antibacterial activity; polar and semi-polar fractions from the aerial parts have shown antibacterial activity. The most active fraction against HCT-116 cell line was the ethyl acetate fraction of seeds. In this assay, water and n-hexane fractions were also active against HCT-116 cell line.

Some of these plants, from the Turkey flora, are used for therapeutic purposes in traditional ways or as a source of active compounds in pharmaceutical industry. Most of the herbal plants in Turkey need to be evaluated and developed as a source for drug discovery technologies.

Podophyllotoxin is the initiation metabolite for the production of etoposide, teniposide, and etopophos, which are used as anticancer drugs clinically. A growing worldwide demand for podophyllotoxin has exerted severe pressure on the plant resource. Therefore, new plant species are needed to obtain this important secondary metabolite. In this study, Linum species growing in Turkey were investigated for their aryltetralin lignan content. Biological activities of $L$. arboreum were also evaluated in addition to their chemical analysis. This study is the first study on the cytotoxic and antimicrobial activity of $L$. arboretum to the best of our knowledge.

\section{Acknowledgement}

This work was financially supported by BAP (University of Ankara University Scientific Research Projects No.18H0237005).

\section{Conflict of interest}

The authors declare no conflict of interest.

\section{References}

1. Alejandre-García I, Álvarez L, Cardoso-Taketa A, González-Maya L, Antúnez M, Salas-Vidal E, Díaz $\mathrm{F}$, Marquina-Bahena $\mathrm{S}$ and Villarreal ML, Cytotoxic Activity and Chemical Composition of the Root Extract from the Mexican Species Linum scabrellum: Mechanism of Action of the Active Compound 6-Methoxypodophyllotoxin. Evid Based Complement Alternat Med., 2015; 2015: 1-11. 
FARMACIA, 2021, Vol. 69, 5

2. Cunha WR, Silva MLA, Veneziani RCS, Ambrósio SR, Bastos JK, Lignans: Chemical and Biological Properties. Phytochemicals. 2012, IntechOpen Limited, London, 213-234.

3. Zare K, Movafeghi A, Mohammadi S, Asnaashari $\mathrm{S}$, Nazemiyeh $\mathrm{H}$, New Phenolics from Linum mucronatum subsp. orientale. BioImpacts, 2014; 4(3): 117-122

4. Yousefzadi M, Sharifi M, Behmanesh M, Moyano E, Bonfill M, Cusido RM, Palazon J, Podophyllotoxin: Current approaches to its biotechnological production and future challenges. Eng Life Sci., 2010; 10(4): 281-292.

5. Saleem M, Kim HJ, Ali MS, Lee YS, An update on bioactive plant lignans. Nat Prod Rep., 2005; 22(6): 696-716

6. Negi AS, Kumar JK, Luqman S, Shanker K, Gupta MM, Khanuja SP, Recent advances in plant hepatoprotectives: a chemical and biological profile of some important leads. Med Res Rev., 2008; 28(5): 746-772.

7. Botta B, Delle Monache G, Misiti D, Vitali A, Zappia G, Aryltetralin Lignans: Chemistry, Pharmacology and Biotransformations. Curr Med Chem., 2011; 8(11): 1363-1381.

8. Javidnia K, Miri R, Rezai H, Jafari A, Azarmehr A, Amirghofran Z, Biological Activity and Aryltetraline Lignans of Linum persicum. Pharm Biol., 2005; 43(6): 547-550.

9. Kartal M, Konuklugil B, Indrayanto G, Alfermann $\mathrm{AW}$, Comparison of different extraction methods for the determination of podophyllotoxin and 6methoxypodophyllotoxin in Linum species. $J$ Pharm Biomed Anal., 2004; 35(3): 441-447.

10. International Conference on Harmonization (ICH). Validation of Analytical Procedures: Methodology, Q2B, 1996. ICH, 2005. Harmonized tripartite guideline: validation of analytical procedures: text and methodology Q2 (R1), www.ema.europa.eu.

11. Singleton VL, Rossi JA, Colorimetry of total phenolics with phosphomolybdic-phosphotungstic acid reagents. Am J Eno. Vitic., 1965; 16(3): 144158

12. Bag GC, Grihanjali P, Bhaigyabati TH, Assessment of total flavonoid content and antioxidant activity of methanolic rhizome extract of three Hedychium species of manipur valley. Int J Pharm Sci Rev Res., 2015; 30(1): 154-159.

13. Shirwaikar A, Shirwaikar A, Rajendran K, Punitha IS, In vitro antioxidant studies on the benzyl tetra isoquinoline alkaloid berberin. Biol Pharm Bull., 2006; 29(9): 1906-1910.

14. Harput US, Genç Y, Khan N, Saracoglu I, Radical Scavenging Effects of Different Veronica Species. Rec Nat Prod., 2011; 5(2): 100-107.
15. Senthil Kumar R, Rajkapoor B, Perumal $P$, Antioxidant activities of Indigofera cassioides Rottl. Ex. DC. using various in vitro assay models. Asian Pac J Trop Biomed., 2012; 2(4): 256-261.

16. Mosmann T, Rapid colorimetric assay for cellular growth and survival: application to proliferation and cytotoxicity assays. J Immunol Methods., 1983; 65(1-2): 55-63.

17. Subcommittee on Antifungal Susceptibility Testing (AFST) of the ESCMID European Committee for Antimicrobial Susceptibility Testing (EUCAST), EUCAST definitive document EDef 7.1: method for the determination of broth dilution MICs of antifungal agents for fermentative yeasts. Clin Microbiol Infect., 2008; 14(4): 398-405.

18. ISO 20776-1:2006 Susceptibility testing of infectious agents and evaluation of performance of antimicrobial susceptibility test devices. Part 1: Reference method for testing the in vitro activity of antimicrobial agents against rapidly growing aerobic bacteria involved in infectious diseases, www.iso.org.

19. Davis PH, Flora of Turkey and the East Aegean Islands, Edinburgh, USA, 1966, vol.: 2, 428 pp.

20. Schmidt TJ, Hemmati S, Klaes M, Konuklugil B, Mohagheghzadeh A, Ionkova I, Fuss E, Alfermann $\mathrm{W}$, Lignans in flowering aerial parts of Linum species - Chemodiversity in the light of systematics and phylogeny. Phytochemistry, 2010; 71(14-15): 1714-1728.

21. Coban $\mathrm{T}$ and Konuklugil $\mathrm{B}$, Free Radical Scavenging Activity of Linum arboreum. Pharm Biol., 2005; 43(4): 370-372.

22. Cowan MM, Plant products as antimicrobial agents. Clin Microbiol Rev., 1999; 12(4): 564-582.

23. Diniz TC, Silva JC, De Lima-Saraiva SR, Ribeiro FP, Pacheco AG, De Freitas RM, Quintans-Junior LJ, Quintans JDES, Mendes RL, Almeida JR. The role of flavonoids on oxidative stress in epilepsy. Oxid Med Cell Longev., 2015; (3): 1-9.

24. Hayouni EA, Abedrabba M, Bouix M, Hamdi M, The effects of solvents and extraction method on the phenolic contents and biological activities in vitro of Tunisian Quercus coccifera L. and Juniperus phoenicea L. fruit extracts. Food Chem., 2007; 105: 1126-1134.

25. Widyawati PR, Budianta WDT, Kusuma FA, Wijaya EL, Difference of Solvent Polarity To Phytochemical Content and Antioxidant Activity of Pluchea indicia Less Leaves Extracts. IJPPR., 2014-15; 6(4): 850-855.

26. Gordaliza M, García P, del Corral AM, Castro M, Gómez-Zurita A, Podophyllotoxin: distribution, sources, applications and new cytotoxic derivatives. Toxicon., 2004; 44(4): 441-459. 